\title{
Traditional Land Governance and Land Conflict Resolutions: The Case of Dormaa Traditional Area, Ghana
}

\author{
Oppong-Kusi Benard Kwame \\ Volta Associates
}

\begin{abstract}
In the Dormaa traditional area (DTA), the majority of the lands are "stool lands" under the customary tenure system. These land administration sometimes overlaps in unclear land ownership and documentation with the statutory land tenure system. These overlapping can lead to land conflicts and a threat to food security. This Paper seek to better understand why people go to traditional Alternative Dispute Resolution (ADR) court for land conflict and what happen at the court. The study is based on semi-structured interviews and ADR court cases analysis. The result clearly shows people go to traditional ADR court due to land trespassing, unclear land ownership and traditional inheritance system. Oral tradition sometimes changes and traditional landmarks disappear causing confusion. The traditional ADR are favored by locals because these places are easily accessible, flexible, and less expensive. The Chief's palace which serve as court also serve as home for the community and easy for disputants to access. Disputants were mostly private individuals although traditional leadership sometimes was involved. The plaintiffs tended to lose due to little understanding about the traditional land laws. This paper recommends the creation of more alternative dispute centers and merging the traditional ADR with statutory ADR.
\end{abstract}

Keywords: alternative dispute resolution; food Security; land conflicts; land governance; land rights 